ФОРМУВАННЯ СПЕЦІАЛЬНИХ ПРОФЕСІЙНИХ КОМПЕТЕНТНОСТЕЙ МАЙБУТНІХ ФІТНЕС-ТРЕНЕРІВ У ЗАКЛАДАХ ВИЩОЇ ОСВІТИ УКРАЇНИ

\title{
THE ARTICLE IS DEVOTED TO ONE OF THE TOPICAL ISSUES OF THE SPECIAL PROFESSIONAL COMPETENCIES FORMATION OF FUTURE FITNESS COACHES IN HIGHER EDUCATION INSTITUTIONS OF UKRAINE
}

у статmі на основі теоретичного аналізу психолого-педагогічної літератури з'ясовано організаційно-методичні аспекти підготовки майбутніх фрітнес-тренерів до професійної діяльності у вищих навчальних закладах. Проаналізовано професійну підготовку майбутніх фрітнес-тренерів у закладах вищої освіти як науково проблему. Окреслено недоліки сучасної системи професійної підготовки фрахівців з оздоровчого фотнесу у вищих навчальних закладах, що призводять до невідповідності рівня їхньої компетентності до соціального запиту, що постійно зростає, і розвитку орітнес-технологій. Досліджено структуру профессійної підготовки майбутніх фрахівців та обгрунтовано значення й зміст праксеологічного компонента в їхній професійній підготовці. З'ясовано профресіональні складники успішної діяльності фрітнес-тренера й охарактеризовано професійно важливі якості його особистості. Проаналізовано вимоги провідних спортивно-оздоровчих центрів, що висуваються до рівня компетентності майбутніх орітнес-тренерів. Сформовано загальну структуру спеціальних професійних компетентностей фітнес-тренера й обгрунтовано їхні квалісрікаційні характеристики згідно з вимогами Єдиного стандарту фрітнесу України. З'ясовано, що рівень розвитку праксеологічного компонента професійної компетентності майбутніх фpimнес-тренерів, який формується в закладах вищої освіти, дає змогу визначити ступінь здатності фрахівців до здійснення ефективної професійної діяльності і становить необхідний обсяг професійних умінь і навичок з надання фрітнес- і рекреаційних послуг різним групам населення. У cmammi зазначені базові і спеціальні трудові фрункції фрітнестренера, на основі яких визначені необхідні компетентності, навички та знання, які необхідно розвивати під час профресійної підготовки майбутніх фрахівців у вищих навчальних закладах. Визначено провідні напрями підвищення профресіональної компетентності орітнес-тренерів відповідно до особливостей майбутньої профресійної діяльності фрахівців з фрітнесу.

Ключові слова: фотнес-тренер, профе сійна підготовка, структура професійної компетентності, спеціальні професійні компетенції, фрітнес-технології, фрітнес стандapm.

The article clarifies the aspects of future fitness trainers' preparation for their professional activity in higher educational institutions on the basis of theoretical analysis of the psychological and pedagogical literature. The system of professional education of fitness trainers is analyzed as a scientific problem. There are outlined the deficiencies of the modern educational system of health fitness specialists' professional training that lead to contradiction of their competence level to the constantly growing social demand and fitness technologies development. The author examines the professional training structure of future fitness trainers and the significance of the development of its praxeological component. There are clarified the professional components of fitness-trainer's success activity and the professionally important qualities of his personality. The professional requirements of the leading sports and health centers to the level of fitness trainer competence are analyzed. The main attention is focused on the research of the general structure of fitnesstrainer's special professional competencies and his qualification characteristics according to the requirements of the Unified Fitness Standard of Ukraine. It was found that the praxeological component level of professional competence of future fitness trainers, which is formed in higher education institutions, allows to determine the degree of professionals ability to carry out effective professional activities. This competence level provides also the necessary amount of professional skills and abilities to future specialists to provide fitness and recreational services on a high level to various population groups. On the base of job functions of a fitness trainer there are determined the needed competencies, skills and knowledge that must be developed during the training of future professionals in higher education institutions. It is also noted the leading directions to increase in the professional competence level of fitness trainers according to features of their future professional activity.

Key words: fitness trainer, professional training, structure of professional competence, special professional competence, fitness technologies, fitness standard.
Донбаської державної машинобудівної академії
Постановка проблеми в загальному вигляді. Уведення профресії «фрітнес-тренер» $€$ новою для спеціальності 017 «Фізична культура і спорт», тому потребує реорганізації традиційної системи підготовки кадрів і створення нових підходів до її проектування. Сучасна система підготовки спрямована більшою мірою на розвиток спортивної майстерності й загальнонаукового компонента освіти майбутніх учителів фрізичного виховання та не розкриває особливості навчання, специфрічність методів, фрорм і засобів професійної підготовки фрітнес-тренерів. Отже, на цьому етапі профресійна підготовка орітнес-тренерів у закладах вищої освіти не забезпечує випускникам високого рівня професіональної компетентності й потребує вдосконалення системи профресійної підготовки, подальшого дослідження та пошуку нових шляхів, методів і засобів фрормування спеціальних компетенцій фітнес-тренерів відповідно до соціального запиту. 
Аналіз останніх досліджень і публікацій. Теоретичний аналіз наукових джерел засвідчує актуальність досліджуваної проблеми. Значна увага досліджень (М. Буренко, 2012; Є. Павлюка, 2014; В. Пономарьова, 2010; В. Пристинського, 2014; Т. Чопик, 2013) приділяється аспектам фахової підготовки майбутніх тренерів у вищих навчальних закладах. Досліджено теоретичні та методичні аспекти підготовки майбутніх орітнестренерів до професійної діяльності (А. Сватьєвим, 2013; М. Василенко, 2012, 2018; А. Боляк, 2012); розглянуто специфіку професійної діяльності фрітнес-тренера (О. Корносенко, 2015; Н. Степанченко, 2017; Л. Сущенко, 2003; О. Ажиппо, 2015, Є. Захаріної, 2015). Група авторів (Ю. Беляк, 2014; П. Слобожанінов, 2017, А. Твеліна 2014) відмічає тенденцію до необхідності вирішення провідної суперечності між суспільною потребою в якісних фрізкультурно-оздоровчих і спортивних послугах і необхідністю оновлення системи підготовки фахівців до тренерської діяльності.

М. Василенко наголошує на проблемі фрормування в майбутніх фрітнес-тренерів готовності до здійснення професійної діяльності, інші (М. Дутчак, 2012; О. Берест, 2016; О. Корносенко, 2015; Т. Круглова, 2007; Є. Приступа, 2017; О. Сайкіна, 2015) - на важливості розв'язання проблеми професійної підготовки фрітнес-тренерів у закладах вищої освіти й указують на невідповідність рівня підготовленості фрітнес-тренерів вимогам роботодавців і необхідність подолання фрагментарного вузькоспеціалізованого навчання цих фрахівців. Група дослідників (О. Атамась, 2013; С. Демеха, 2013; М. Дутчак, 2012; О. Жданова, 2014; І. Іванов, 2014; О. Кібальник, 2014; К. Короленко, 2014) акцентують увагу на фрормуванні змісту, доборі методів, форм і засобів підготовки майбутніх фрітнес-тренерів.

Виділення не вирішених раніше частин загальної проблеми. На нашу думку, недостатньо обґрунтовані теоретичні й методичні засади професійної підготовки фрітнес-тренерів, а саме зміст навчання, організаційно-педагогічні умови, методи та система засобів, що забезпечить готовність майбутніх фрахівців до професійної діяльності. Проблема полягає в невизначеності системи професійної підготовки майбутніх фрітнес-тренерів і засобів формування спеціальних компетенцій фрітнес-тренерів, що забезпечить майбутнім фрахівцям готовність до профресійної діяльності. Отже, недостатня теоретична розробленість професійної підготовки майбутніх фрітнес-тренерів у закладах вищої освіти відповідно до сучасного рівня розвитку оздоровчих фрітнес-технологій і соціальна значимість означеної профресії, що зростає, зумовили мету дослідження.

Мета статті - теоретичне дослідження спеціальних компетенцій майбутніх фрітнес-тренерів, виявлення профресійно важливих особистісних якостей фрітнес-тренера та розгляд концептуальних засад системи професійної підготовки майбутніх фрітнес-тренерів у закладах вищої освіти.

Виклад основного матеріалу. Професійна підготовка майбутніх фрітнес-тренерів у закладах вищої освіти зобов'язана сорормувати профресійну компетентність випускників, що дасть їм змогу після завершення освітньої програми успішно реалізувати отримані знання та професійні навички в діяльності 3 надання фрітнес-послуг для різних груп населення 3 урахуванням сучасних вимог суспільства. На нашу думку, М. Василенко найбільш повно розкрила сутність професійної компетентності фрітнес-тренерів, що фрормується в закладах вищої освіти. Автор трактує поняття як інтегративну характеристику особистості, яка $€$ результатом підготовки випускника закладу вищої освіти, визначається сформованістю знань, умінь і навичок, професійно важливих, світоглядних і громадянських якостей, що в сукупності забезпечує можливість виконання ними професійних обов'язків із задоволення потреб населення у фрізичному вдосконаленні, збереженні й відновленні здоров'я, активному відпочинку та реалізується відповідно до розроблених орітнес-програм і рекомендацій у фрорматі індивідуальних або групових занять [5, с. 315].

3'ясування професіональних складників діяльності фрітнес-тренера $€$ необхідним для подальшого проектування змісту професійної підготовки майбутніх фрітнес-тренерів. Поняття успішності тренера з фрітнесу може бути досягнуто завдяки розвитку сукупності професійно важливих якостей його особистості, таких як універсальність технічних, методичних та організаційних навичок; уміння програмувати заняття для осіб 3 фракторами ризику захворювань; бажання й уміння навчатися; уміння спілкуватися іноземною мовою; уміння продавати фрітнес-послуги, уміння керувати мотивацією споживача фрітнес-послуг; уміння здійснювати контроль за фрізичним станом споживача фрітнеспослуг; педагогічна майстерність; харизма та приємна зовнішність; артистизм; креативність; уміння безконфрліктного спілкування; комунікабельність; упевненість у собі; уміння надавати консультації з раціонального харчування та здорового способу життя [6, с. 98; 7, с. 121].

Перспективним напрямом фрормування профресійної компетентності студентів - майбутніх фрітнес-тренерів - $€$ пошук шляхів відповідної організації підготовки до профресійної діяльності під час навчання у вищому навчальному закладі. Дослідження Е. Павлюка дали підставу вважати, що еорективна підготовка майбутніх тренерів можлива за таких педагогічних умов: фрормування професійно-мотиваційного виховного простору; взаємодія закладу вищої освіти та підприємств ринку 
фрітнес-послуг; адаптивність і гнучкість освітнього процесу; забезпечення зворотного зв'язку при взаємодії викладачів і студентів; забезпечення профресійної самоосвіти й самовдосконалення майбутніх тренерів-викладачів у процесі фрахової підготовки; розуміння професійної мотивації як процес формування фрахових орієнтацій майбутніх фрахівців. Під педагогічними умовами професійного становлення Е. Павлюк визначає сукупність взаємозалежних елементів освітнього середовища - факторів, що визначаються й усвідомлюються учасниками педагогічної взаємодії, реалізуються в навчально-виховному процесі ВН3, спонукають викладачів і студентів до активізації власної діяльності з метою оптимізації професійного становлення майбутніх тренерів у процесі фрахової підготовки й зумовлюють підвищення есрективності процесу фрахової підготовки фрахівців з вищою освітою [13, с. 109].

3 огляду на теоретичні розробки в дослідженні структури профресійної компетентності, на наш погляд, найбільш обґрунтованою є розробка цієї структури автором М. Василенко (рис. 1), відповідно до якої базова структура професійної компетентності фрітнес-тренерів, що фрормується в закладах вищої освіти, має складатися 3 таких основних компонентів: мотиваційний, аксіологічний, гносеологічний, особистісний і праксеологічний, та утворюватися системою загальних, базових і спеціальних компетентностей (дидактично-рухової, проектувально-конструкторської, контрольно-аналітичної, організаційно-регулятивної, мотиваційно-комунікативної та маркетинговокомерційної) [6, с. 101].

Вихідними позиціями при структуруванні професійної компетентності фрітнес-тренерів, яка формується в закладах вищої освіти, є розуміння, що кожний компонент характеризує певну властивість, здатність або здібність особистості, що є, на думку М. Василенко, фрундаментом для успішної реалізації професійних фрункцій фрітнес-тренерів. Мотиваційний компонент професійної компетент- ності фрітнес-тренерів характеризується наявністю професійної спрямованості особистості; аксіологічний - визначає ступінь її здатності до самовизначення, цілепокладання й актуалізації власних потенціалів; гносеологічний - характеризується комплексом соціально-гуманітарних, фундаментальних і професійних знань і сорормованих академічних здібностей; праксеологічний - відображає ступінь здатності майбутніх фрітнес-тренерів до здійснення ефективної професійної діяльності та становить необхідний обсяг спеціальних компетенцій [7, с. 119].

Крім того, автор наголошує, що в процесі розробки системи професійної підготовки майбутніх фрітнес-тренерів у закладах вищої освіти мають бути враховані такі здобутки світового досвіду: тісна співпраця 3 роботодавцями; орієнтація змісту професійної підготовки майбутніх орітнестренерів на формування в студентів здатності до безконфрліктного спілкування, мотивування клієнтів, до розробки та проведення фрітнес-програм оздоровчо-профрілактичної спрямованості 3 різними групами населення; активне застосування різноманітних форм навчання студентів; диверсифікація освітніх послуг; узгодження національних реєстрів освітніх кваліфікацій тренерів різних країн і поширення практики створення міжнародних освітніх програм [10, с. 20].

Сьогодні єдиним стандартизованим підходом до визначення переліку трудових функцій, загальних і спеціальних компетенцій, необхідного обсягу знань, умінь і практичних навичок фрітнес-тренера ми пропонуємо вважати розробку профресійного стандарту для фрітнес-тренера у сорері оздоровчого фрітнесу, упровадженого Національним університетом фрізичного виховання і спорту України спільно 3 аналітично-консалтинговою установою FitnessConnectUa [9]. Профресійний стандарт розроблено для встановлення контролю якості у сорері надання фрітнес послуг, здійснення ефрективної кадрової політики в організаціях фрітнесіндустрії та підвищення кваліфрікації фрахівців, що

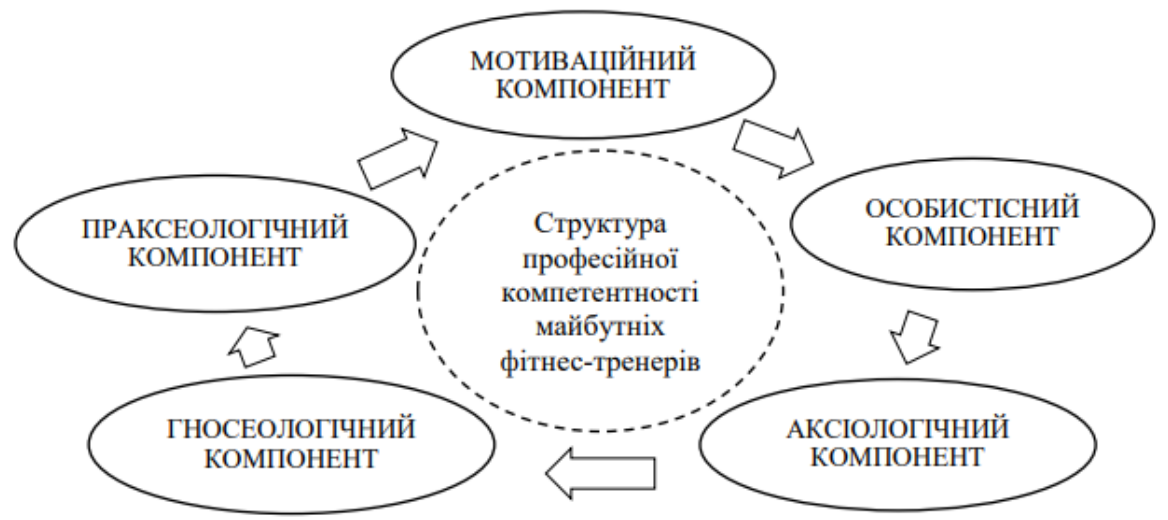

Рис. 1. Структура професійної компетентності майбутніх фрітнес-тренерів, що формується в закладах вищої освіти 
впливатиме на якість надання фрітнес-послуг різним верствам населення.

На основі розробленого стандарту, що затверджує орормування єдиних стандартів і критеріїв оцінювання компетенцій фрітнес-тренера в різних підрозділах (групових програм, персонального тренінгу, аквафрітнесу та дитячих програм), нами запроваджено єдину модель для фрормування спеціальних компетенцій майбутніх фрітнес-тренерів відповідно до сучасного рівня розвитку ринку фрітнес-послуг (рис. 2). Підготовка фрахівців за означеними трудовими ффункціями забезпечить фрормування праксеологічного компонента їхньої професійної компетентності, що сприятиме підвищенню рівня підготовленості фрітнес-тренерів у вищих навчальних закладах до вимог роботодавців і забезпечить готовність майбутніх фрахівців до просресійної діяльності.

Треба зазначити, що визначені спеціальні компетентності є єдиними базовими вміннями фрітнес-тренера, за напрямами яких має здійснюватися підготовка майбутніх фрахівців у ВНЗ, однак ми наголошуємо на необхідності проходження обов'язкової фрахової практики студентами в спортивно-оздоровчих закладах за обраним фрітнес-підрозділом 3 урахуванням їхніх профресійних навичок і здібностей. Ми вважаємо, що такий підхід забезпечить максимальний ступінь підготовки майбутніх фрітнес-тренерів до здійснення ефективної професійної діяльності та сприятиме реалізації їхніх сильних профресійних сторін як висококваліфікованих спеціалістів у сорері оздоровчого фрітнесу.

Базові трудові фрункції фрітнес-тренера включають розробку програм індивідуальних і групових занять з урахуванням вікових та індиві- дуальних особливостей клієнтів, організацію та проведення занять, здійснення педагогічного контролю в процесі занять, дотримання вимог внутрішнього розпорядку, техніки безпеки й охорони праці з урахуванням фрормату заняття та специфіки контингенту.

Перш ніж приступити до розробки будь-якої програми з фрітнесу, тренер має провести первинні дослідження, включаючи діагностику антропометричних, фрункціональних даних клієнта, стан його фрізичної підготовленості, психоемоційний стан, оцінку показників здоров'я, виявлення фракторів ризику розвитку захворювань, рухового досвіду з використанням сучасних методів діагностики й тестів [1, с. 4]. Для занять фрітнесу, що потребують спеціальної фрізичної підготовки, важливо оцінити наявні навички спеціальної підготовленості клієнтів (техніка плавання, виконання складно-координаційних вправ $з$ кросфіту, боксу, тощо) як передумови побудови оздоровчих занять 3 обраної програми фрітнесу. Результатом первинного дослідження $є$ етап узагальнення й аналізу результатів діагностики, визначення спрямованості й завдань занять, методів контролю, критеріїв ефективності 3 урахуванням морфо-фрункціональних, вікових особливостей, рівня фрізичної підготовленості.

Основною базовою трудовою фрункцією фрітнес-тренера $€$ програмування орітнес-занять для різних категорій населення 3 урахуванням їхніх індивідуальних особливостей. Базовою компетенцією фрітнес-тренера залежно від обраного фрітнес-підрозділу $€$ вміння розробляти групові чи індивідуальні заняття аеробної, фрункціональної, силової, ментальної спрямованості, засобів аквафрітнесу чи засобів оздоровчо-рекреаційної рухової активності для дітей і підлітків з урахуван-

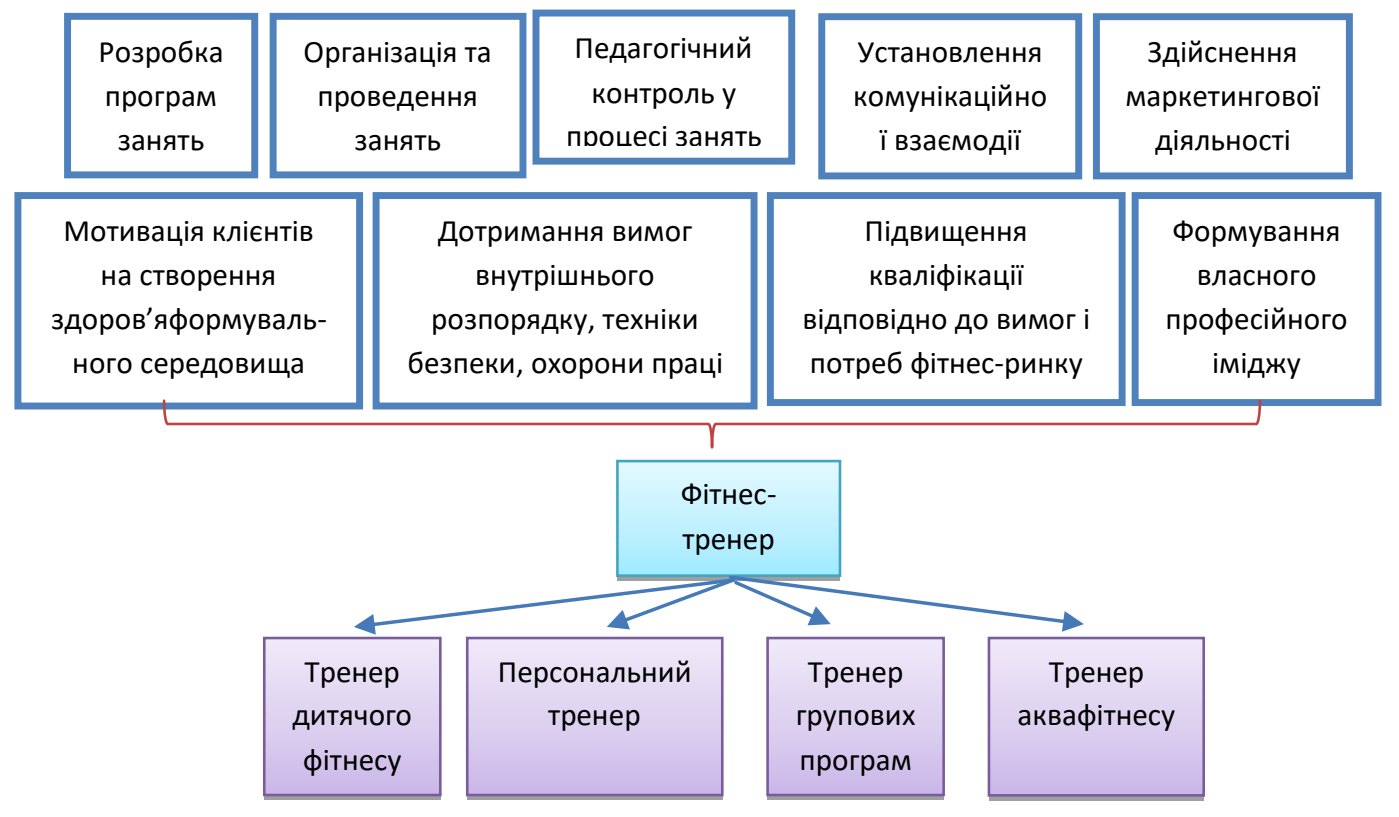

Рис. 2. Спеціальні компетенції майбутніх фітнес-тренерів за вимогами роботодавців 
ням формату заняття з визначенням етапів, мети, загальних і спеціальних завдань, засобів, методів, параметрів навантаження, фрорм організації, термінів і методів контролю, критеріїв ефрективності програми занять [9]. Варто відмітити важливість уміння тренера проектувати й розробляти програми занять фрізичними вправами для категорій населення різної статі, віку, фрізичного стану з урахуванням методичних принципів побудови занять, їх регламенту: для осіб з інвалідністю чи осіб, що мають наявні захворювання або фрактори ризику виникнення захворювань серцево-судинної системи, обміну речовин, опорно-рухового апарату, з урахуванням їхніх індивідуальних особливостей; для дітей, підлітків та осіб похилого віку з урахуванням вікових особливостей контингенту; для жінок у період вагітності й післяпологовий період з урахуванням фрізіологічних особливостей у кожному триместрі вагітності та в післяпологовий період [12, с. 173].

Відмінною особливістю персонального тренера $€$ вміння застосовувати принципи клієнт орієнтованості й індивідуального підходу при розробці програми занять і прогнозувати результати впливу програми занять на фрізичний стан клієнтів. Ключовою компетенцією тренера при індивідуальній роботі 3 клієнтом є вміння розробляти та надавати рекомендації для різних категорій населення щодо організації харчування, характеру відпочинку й засобів відновлення після занять, організації самостійної рухової активності з урахуванням спрямованості тренувального процесу.

Для тренерів дитячого фрітнесу важливо навчитися планувати, організовувати та проводити для дітей і підлітків заняття загальної фрізичної підготовки, розвивальної спрямованості чи спрямовані на корекцію постави, 3 використанням засобів спортивних, рухливих, рекреаційних ігор з урахуванням методичних принципів побудови занять та їх відповідності віковим особливостям контингенту [4, с. 204]. Крім того, необхідно вміти організовувати активне дозвілля для дітей і членів їхньої родини під час перебування як у клубі, так і занять, фрізкультурно-оздоровчих і масових заходів на відкритому повітрі (змагання, відкриті заняття, показові виступи, заходи з різних видів рухової активності, тематичні зустрічі).

Передовою функцією успішного тренера цього підрозділу є постійний пошук і впровадження педагогічних інновацій при організації занять і дозвілля дітей. Цей напрям його діяльності має включати використання сучасних педагогічних теорій, технологій, методів організації занять та аналіз наявних чи розробку нових фрітнес-програм, ігор, нових форматів проведення розвивальних занять (спрямованих на розвиток когнітивної сорери, інтелектуальних здібностей, тощо), які можуть бути застосовані для дітей різного віку, статі з використанням сучасного обладнання та матеріально-технічної бази фрітнес-клубу [9].

Проведення персонального чи групового тренування передбачає вміння організовувати та проводити заняття відповідно до розробленої програми з використанням засобів силової, аеробної, фрункціональної, ментальної спрямованості, засобів аквафрітнесу чи засобів оздоровчо-рекреаційної рухової активності для дітей і підлітків залежно від обраного фрітнес підрозділу. Обов'язковим $€$ знання тренером профресійної термінології, уміння використовувати вербальні та невербальні команди в процесі проведення заняття; здійснення підбору музичного супроводу для забезпечення емоційної насиченості занять з урахуванням методичних вимог та особливостей фрормату заняття [2, с. 115]. Під час проведення заняття тренер має вміти демонструвати досконале технічного виконання фрізичних вправ, навчати правильної техніки виконання фрізичних вправ із використанням відповідних методів навчання, здійснювати контроль за технікою виконання вправ, модифрікувати техніку виконання фрізичних вправ з урахуванням індивідуальних особливостей клієнта чи групи. Не менш важливими є здобуття навиків використання методів мотивації та стимулювання активності клієнта в процесі заняття.

Важливою фрункцією фрітнес-тренера $€$ здійснення педагогічного контролю в процесі занять, який являє собою моніторинг інтенсивності виконання фрізичних вправ. Обов'язковими для діяльності тренера $€$ навички здійснення контролю за адекватністю фрізичних навантажень у процесі заняття відповідно до рівня фрізичного стану клієнта чи групи за об'єктивними та суб'єктивними ознаками й надання відповідних методичних рекомендацій. Для оцінювання ефективності обраної програми проводиться обстеження фрунцціонального стану клієнта (експрес-контроль, поточний та етапний) та аналіз показників впливу фрітнес-програми на організм, відстежується прогрес клієнтів і за необхідності коригується зміст фрітнес-програми [10, с. 17].

У процесі здійснення своєї трудової діяльності фрітнес-тренер має вміти створювати психологічно-комфортну атмосферу при спілкуванні 3 клієнтами, установлювати комунікаційної взаємодії 3 клієнтами з урахуванням психологічних і вікових особливостей контингенту, тактично взаємодіяти із суміжними підрозділами клубу, дотримуватися субординації в спілкуванні 3 клієнтами, керівництвом і співробітниками.

Для здійснення успішної професійної трудової діяльності фрітнес-тренер має також виконувати такі суміжні функції, як мотивація клієнтів на створення здоров'я фрормувального середовища, здійснення маркетингової діяльності з продажу персональних занять і додаткових послуг фрітнес-клубу, постійне підвищення кваліфрікації відповідно до 
вимог і потреб фрітнес-ринку, фрормування власного професійного іміджу (діяльність у соціальних мережах, презентація занять на фрітнес-конвенціях, участь у змаганнях) (рис. 2).

Треба зазначити, що в сучасних фрітнес-центрах простежується тенденція до відкриття нових фрітнес-підрозділи з метою надання більш широкого розмаїття фрітнес-програм. Провідні фрітнес-клуби намагаються представити своїм клієнтам не тільки заняття в тренажерному залі, залах групових програм, басейні, а й відкривають нові зони, такі як зал для кросоріту, єдиноборств, реабілітаційних програм. Високий рівень конкуренції та розвиток фрітнес-технологій призводить як до постійного вдосконалення і зростання матеріально-технічної бази, так і появи нових фрорматів і методів проведення оздоровчих занять (рис. 3). Тому ми наголошуємо на оновлені інорормаційного складника та змісту навчально-методичних комплексів системи 3 професійної підготовки майбутніх фрітнес-тренерів у закладах вищої освіти [3, с. 71; 5, с. 375], зокрема розширення циклу дисциплін професійної і практичної підготовки: «Аеробіка», «Силовий фрітнес», «Функціональний тренінг», «Танцювальна аеробіка», «Ментальний фрітнес», «Аквафітнес», «Реабілітаційні програми». Ми вважаємо, що впровадження зазначених дисциплін до системи підготовки майбутніх фрітнес-тренерів у закладах вищої освіти не тільки сприятиме формуванню мотиваційного, гносеологічного, особистісного та праксеологічного компонентів їхньої профресійної компетентності, а й дасть змогу ссрормувати нове покоління висококваліфрікованих спеціалістів широкого профрілю в галузі оздоровчого фрітнесу.

Висновки. Професійна підготовки майбутніх фрітнес-тренерів у закладах вищої освіти має бути орієнтована на фрормування в студентів спеціальних професійних компетенцій відповідно до сучас- них вимог ринку з фрітнес-послуг і трудових фрункцій, покладених на фрахівців з оздоровчого фрітнесу. На основі теоретичного аналізу дослідження окремих аспектів підготовки майбутніх фрітнес-тренерів до професійної діяльності визначено загальну структуру спеціальних компетенцій майбутніх фрітнес-тренерів згідно 3 кваліфрікаційними вимогами Єдиного стандарту фрітнесу України як основи для фрормування праксеологічного компонента в загальній системі їх підготовки у вищих навчальних закладах. Визначення спеціальних компетенцій майбутніх фрахівців на основі трудових фрункцій фрітнес-тренера з урахуванням сучасних вимог роботодавців і ринку фрітнес-послуг, що постійно розвивається, вивчення проблеми професійного становлення майбутніх тренерів у процесі фрахової підготовки у вищому навчальному закладі, визначення сутнісних характеристик провідних структур професійної компетентності й аналіз професійних функцій реальної практики сучасних фрахівців повною мірою може стати достатньою науковою підставою для вдосконалення пракселогічного компонента системи їхньої професійної підготовки та забезпечення педагогічних умов системи професійного становлення майбутніх фрітнес-тренерів у процесі фрахової підготовки. Перспективи для подальших досліджень убачаємо в удосконаленні системи профресійної підготовки майбутніх фрітнестренерів відповідно до Стандарту вищої освіти першого (бакалаврського) рівня освіти галузі знань 01 «Освіта», спеціальності 017 «Фізична культура і спорт», спеціалізації «Фітнес»; у вдосконаленні змісту навчально-методичних комплексів системи з профресійної підготовки майбутніх фрітнес-тренерів, а також у забезпеченні фрахового стажування студентів у провідних спортивно-оздоровчих центрах відповідно до обраного фрітнес-підрозділу та подальшій співпраці з роботодавцями.

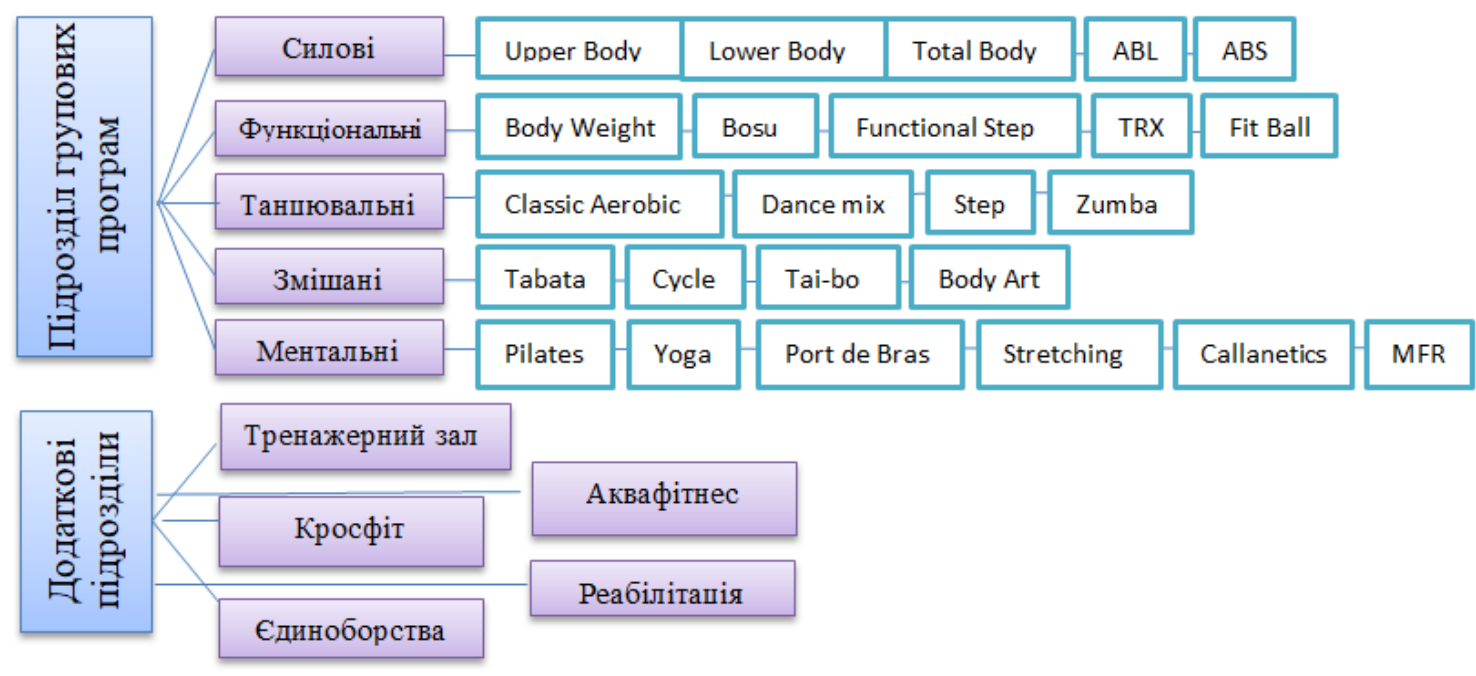

Рис. 3. Фітнес-підрозділи та сучасні програми з оздоровчого фрітнесу 


\section{БІБЛІОГРАФІЧНИЙ СПИСОК:}

1. Беляк Ю.І. Класифрікація та методичні особливості засобів оздоровчого фрітнесу. Педагогіка, психологія та медико-біологічні проблеми фрізичного виховання і спорту. Івано-Франківськ : Прикарпатський національний університет ім. В. Стефаника, 2014. № 11. C. 3-7.

2. Берест О.О. Сучасний стан проблеми підготовки фрітнес-тренерів. Вісник Глухівського національного педагогічного університету ім. Олександра Довженка. Серія «Педагогічні науки». 2016. Вип. 31. С. 113-122.

3. Системний підхід у профресійній діяльності тренера 3 фрітнесу : навчальний посібник / А.А. Боляк, Н.Л. Боляк, О.В. Корх-Черба, П.М. Кизім. Харків : ХДАФК, 2012. 130 c.

4. Буренко М.С. Формування фрахових компетенцій майбутніх тренерів-викладачів у процесі вивчення циклу професійно-орієнтованих дисциплін : дис. ... канд. пед. наук : 13.00.04 / Класич. приват. ун-т. Запоріжжя, 2012. 224 с.

5. Василенко М.М. Професійна підготовка майбутніх фрітнес-тренерів у закладах вищої освіти: теорія та методика : монографрія. Київ : Центр учбової літератури, 2018. 495 с.

6. Василенко М.М. Стан готовності майбутніх фрахівців до діяльності у сорері фрітнес-індустрії. Педагогіка формування творчої особистості у вищій і загальноосвітній школах : збірник наук. праць. Запоріжжя : Класичний приватний університет, 2014. С. 98-102.

7. Василенко М.М. Сучасні вимоги роботодавців до фрормування готовності майбутніх фрітнес-тренерів до професійної діяльності. Педагогіка фрормування творчої особистості у вищій $і$ загальноосвітній школах. 2014. С. 119-124.

8. Демеха С. Технологія управління фрізкультурними кадрами в організаціях фрітнес спрямованості.
Фізичне виховання, спорт, культура здоров'я в сучасному суспільстві. 2013. С. 9-12.

9. Єдиний фрітнес стандарт України : Наказ Міністерства соціальної політики України від 22.01.2018 № 74. URL: https://www.uastandart.fitness.

10. Дутчак М.В., Василенко М.М. Теоретичне обґрунтування кваліфрікаційної характеристики фрітнес-тренера. Педагогіка, психологія та медико-біологічні проблеми фрізичного виховання і спорту. Харків : ХОВНОКУ, 2013. № 2. С. 17-21.

11. Корносенко О. Професійна підготовка майбутніх фрітнес-тренерів як педагогічна проблема. Молода спортивна наука України : збірник наук. пр. з галузі фріз. виховання і спорту / за заг. ред. Є. Приступи. Львів, 2016. Вип. 20, Т. 3/4. С. 85-91.

12. Корносенко О.К. Специфіка і фрункції профресійної діяльності фрітнес тренера. Педагогічні аспекти профресійної підготовки майбутнього фрахівця з фрізичного виховання та спорту. 2015. C. $173-177$.

13. Павлюк Є.О. Профресійна компетентність як складова профресійної діяльності майбутніх тренерів-викладачів. Збірник наукових праць Національної академії Державної прикордонної служби України. Серія «Педагогічні та психологічні науки». 2014. № 2. С. 109-117.

14. Сайкина Е.Г, Смирнова Ю.В. Актуализация профессиональной подготовки специалистов по фритнесу в высших учебных заведениях в условиях новых образовательных стандартов. Современные проблемы науки и образования. 2015 № 3. URL: http:scienceeducation.ru/ru/article/ view?id=17499.

15. Степанченко Н.І. Система профресійної підготовки майбутніх учителів фрізичного виховання у вищих навчальних закладах : дис. ... докт. пед. наук : 13.00.04. Вінниця, 2017. 629 с. 